nych i refleksji teologicznej. Toteż dziś krytyka koncentruje się na bezspornym fakcie katastrofy narodowej $587 \mathrm{r}$. przed Chr. i niewoli babilońskiej. Spowodowały one zmianę w sposobie myślenia narodu i nadały jego religijności nowy kierunek. Nic więc dziwnego, że redakcje końcowe powstałe właśnie w tym czasie, znalazły się w centrum zainteresowania krytyki. Prawda, że założenia te wymagają wielu prac analitycznych, literackich i filologicznych, ale rozwój badań zmierza wyraźnie w tym kierunku.

Zmianie uległa wreszcie ocena stosunku tradycji biblijnych do pozabiblijnych przekazów starowschodnich, choć bynajmniej nie w sensie uzależnienia wątków Starego Testamentu od tamtych. Można to pokazać na przykładzie opisu potopu biblijnego. Pomijając propozycje skrajne i odosobnione, np. krytycznego skądinąd egzegety z Izraela Rapporta, który wzbrania się przyjąć jakąkolwiek zależność Rdz 6-9 od znanego eposu Gilgamesz ${ }^{43}$, trzeba powiedzieć, iż niemal wszyscy krytycy podkreślają przy wspólnych motywach kulturowych oryginalność argumentacji teologicznej opowiadania biblijnego; chodzi nie tylko o atmosferę monoteizmu, ale i motywy sprowadzenia kataklizmu takie jak powszechna grzeszność, inicjatywa Boża wynikająca z Jego stwórczej woli, gwarancje dla świata popotopowego itp.

Przytoczone uwagi dotyczyły głównie problemów związanych z Pięcioksięgiem, ale sięgały swym wpływem także na inne zagadnienia współczesne Starego Testamentu. Niepodobna w niniejszym referacie omówić ich choćby pobieżnie. Chodziło raczej o naszkicowanie kierunków, w które zmierza współczesna krytyka Starego Testamentu. Z pewnością nie chce ona być ostatnim słowem w debacie nad dawnym posłannictwem Boga do Jego ludu. Takie słowo wypowiedział w swym zbawczym czynie i w Nowym Testamencie sam Jezus Chrystus. Chce ona jednak przybliżyć wspólczesnemu człowiekowi końca XX wieku bogactwo mądrości Bożej, kierowane przecież do określonej społeczności w określonym czasie. Chce, byśmy łatwiej i pełniej odnaleźli się jako lud Boży nowy, ucząc się odczytywać słowo Pańskie, które przemawia i fascynuje wczoraj i dziś.

Łódź

KS. LECH STACHOWIAK

43. I. Rapport, Tablet XI of the Gilgamesh Epic and the Biblical Flood Story. A Refutation of the generally held View that Genesis 6-9 is based upon a Babylonian Prototype, Tel Aviv 1981.

Ks. Tadeusz Brzegowy

\title{
JERUZALEM - MIASTO POKOJU. PRZYCZYNEK DO TEOLOGII ZBAWIENIA W PSALMACH
}

Zbawienie jest pojęciem kluczowym języka biblijnego. Gdy w języku greckim pojęcie to oddaje jeden termin sodzō, to w hebrajskim autorzy muszą się 
uciekać do całej gamy terminów, obrazów, metafor. Ich podstawowe znaczenie to „być ocalonym”, „być uwolnionym od nieszczęścia czy niebezpieczeństwa". Chodzi tu zawsze o akt opieki, wyzwolenia, wykupu, uleczenia, zwycięstwa. Terminami najbliższymi, najczytelniejszymi metaforami, najdokładniejszymi synonimami „zbawienia” w Biblii hebrajskiej i zwłaszcza w psalmach są „życie” i „pokój”. „Życie” według psalmistów to jakieś niezachwiane trwanie i rozwijanie aktywności na tym świecie, to jakaś potrzeba i możność jego przedłużenia i wzbogacenia, to ostatecznie jakaś pełnia życia w uszczęśliwiającym zjednoczeniu z Bogiem ${ }^{1}$. Zaś ,pokój”, to nie tylko brak wojny, ale to dobrobyt codziennego istnienia, jakaś harmonia bycia człowieka z Bogiem, z bliźnimi, z sobą samym, to suma dóbr towarzyszących sprawiedliwości, to triumf nad nieprzyjaciólmi, to bezpieczne mieszkanie w urodzajnej ziemi, to wszystko, przez co Bóg jest z nami (Kpł 26,1-13), słowem - to pełnia szczęścia $^{2}$.

Izrael wierzył niezachwianie, że zbawienie jest darem Boga (Ps 44,4.7n) i że poza Bogiem nie ma zbawienia (Iz 43,11 por. 47,15 ; Oz 13,4). Wszelkie ludzkie środki na nic się tu nie zdadzą (Ps 33, 16-19), gdyż tylko Bóg jest zbawicielem (Ps 27,1; 35,3; 37,39n; 62,7 etc). Jahwe zbawial w historii, w czasie obecnym, i wyglądano Jego ostatecznego zbawienia przy końcu czasów. Wspomnienie ocaleń w przeszłości Izraela było dla pobożnych motywem niezachwianej ufności w godzinach ucisku (Ps 22,6; 107,13.19.28).

Klasycznego przykładu zbawienia w historii narodu wybranego dostarczała Jerozolima: Sennacheryb drwił sobie z Jahwe, jakoby On był w stanie ocalić Jerozolimę z rąk Asyryjczyków (2 Krl 18,30-35). Ale Izajasz przyrzeka w imię Jahwe ocalenie. (2 Krl 19,34; 20,6). Tej samej nocy moc Boża pobiła nieprzyjaciół, a rankiem Izraelici mogli oglądać ich zagładę $(2 \mathrm{Krl} 19,35)$. Ten ostatni przykład stanowi znakomite wprowadzenie do rozważań nad związkiem, jaki zachodzi między Jerozolimą i zbawieniem.

Albowiem to ze swej królewskiej stolicy Jahwe odbywał sąd, wymierzał sprawiedliwość. Ale ten sąd nie był celem sam dla siebie i nie był nigdy ostatnim słowem Boga nad stworzeniem. Dokonując sądu, który jest raczej skarceniem, Bóg otwierał drogę zbawienia. Boże szafowanie sprawiedliwości było właściwie zawsze ocaleniem jakichś zagrożonych wartości, uciśnionego narodu czy jednostki ${ }^{3}$. Jak w boskim wymiarze sprawiedliwości, tak i w rozdawnictwie zbawienia Jerozolima jest uprzywilejowanym miejscem na ziemi. Stąd, to znaczy z miejsca obecności Jahwe, spływa zbawienie najpierw na samo Miasto Święte (1), na króla Izraela (2), na naród wybrany (3) i na wszystkie narody (4).

1) Wymowny i wzruszający obraz Jerozolimy jako „miasta pokoju” przynosi Ps 122 , utkany w asonancji wyraźnych i ukrytych z imieniem miasta. Nazwa miasta „Jeruzalem” została użyta w psalmie trzy razy, co na pewno jest za-

1. Por. J. W. Rosłon, Zbawienie jako życie w oparciu o Księgę Psalmów, RBL 39 (1986) 177-197; C. Lesquivit - P. Grelot, Zbawienie, STB 1117-23.

2. Por. X. Léon - Dufour, Pokój, STB 700-705.

3. H. Cazelles, Juges, DBSuppl IV, 1396. 
mierzone, wyznaczając trzy sekcje utworu: na końcu introdukcji (ww.1-2) i na rozpoczęcie dwóch strof psalmu (ww. 3-5 i 6-9). Dla starożytnych Hebrajczyków było rzeczą zupełnie naturalną, że nomen est omen. Pobobnie rzecz się miała wśród starożytnych pisarzy greckich, którzy nazwę Jeruszalem najczęściej interpretowali jako hórasis eirēne $\bar{s}^{4}$, skąd wzięło się lacińskie tlumaczenie

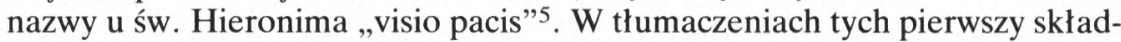
nik nazwy jrw jest związany z rdzeniem hebrajskim $r$ ' $h$, widzieć. Sławny hymn średniowieczny „Caelestis urbs Jerusalem, beata visio pacis” spopularyzował tę interpretację i zepchnął na dalszy plan inne ${ }^{6}$. Współcześni autorzy zaznaczają najczęściej tę paronomazję, ale w odniesieniu tylko do drugiej części nazwy. I tak A. Weiser ${ }^{7}$ ujmuje to zjawisko następująco: „W języku oryginalnym dźwięczy w słowach «pokój» i «zbawienie» (šâlôm) druga część składowa nazwy Jerozolimy, co dla ludzi starożytnych było czymś więcej niż tylko wyszukaną grą wyrazów". L. Alonso Schökel i A. Strus ${ }^{8}$ nawiązując do autorów starożytnych, uważają że Ps 122 spożytkowuje dźwiękowe podobieństwa obydwóch części imienia Jerozolimy. Starożytnego poety, jak i słuchacza - odbiorcy poezji, nie interesowała naukowa etymologia nazwy ${ }^{9}$, lecz wystarczało mu dźwiękowe podobieństwo wyrazów, by kojarzyć ich znaczenia. Przykłady podobnych ludowych etymologii w Starym Testamencie są bardzo liczne, choćby wspomnieć takie imiona jak Abraham, Jakub, Izrael. Druga część nazwy jrwšlm jest oczywiście związana w psalmie z wyrazem šālôm, pokój. Zaś pierwsza część tej nazwy jrw, dzięki temu, że Jerozolima była uważana za miasto par excellence i mogła być określana po prostu mianem „miasta”, jak Rzym słowem „Urbs”, została skojarzona z hebrajskim wyrazem $i r$, tzn. miasto. Przejście dźwiękowe jrw - jeru - iru - ir wydaje się całkiem naturalne. Tak więc i konstrukcja psalmu da się widzieć w owym muzyczno-dźwiękowym założeniu poety. Introdukcja $(1-2)$ zapowiada temat psalmu: jak radosną jest rzeczą znaleźć się w obrębie miasta Jerozolimy z delikatną asonancją jerušălāim — šearaik (Jeruzalem - twoje bramy). Pierwsza strofa (3-5) rozwija temat miasta, ośrodka kultu i sądownictwa „Jeruzalem, zbudowane jak miasto” (3a) z dość wyraźną konsonancją jeru — ir. W drugiej strofie temat miasta pozostaje

4. Euzebiusz z Cezarei, In Ps 75: „Salēm men gar hermēneuetai eirēnē, Hierousalēm de horasis eirēnēs. Według św. Hieronima, PL 23, 783. Także Filon, Orygenes, Cyryl Al., Prokopiusz iin. Zob. F. Wu t z, Onomastica sacra, Leipzig 1914, $110 \mathrm{i}$ passim.

5. Sw. Hie ronim, Liber de nominibus hebraicis, PL 23,829: „Salem enim pax interpretatur, Jerusalem autem visio pacis". Tłumaczeniem tym chętnie posługuje się św. Augustyn w Enarrationes in Psalmos. Zob. F. W u tz, Onomastica sacra, 109 i passim.

6. Inne tłumaczenia to horos eirēnēs ,góra pokoju” (hebr. har šâlôm), lub hieron eirē$n \bar{e} s$ „sanktuarium pokoju”, przy zastosowaniu greckiej etymologii do pierwszej części imienia. Zob. F. Wutz, Onomastica sacra, 238 i passim.

7. A. We is e r, Die Psalmen (ATD 14/15), Göttingen 61963,500 ; podobnie rzecz objaśniał A. F. Kirkpatrick, The Book of the Psalms, Cambridge 1957, 741.

8. L. Alonso Schökel - A. Strus, Salmo 122, Canto al nombre do Jérusalén, Bib 61 (1980) $234-250$.

9. W naukowej etymologii nazwa „Jeruszalem” znaczy tyle co „fundacja (boga) Szalema". Zob. G. Fohrer, Siōn, TWNT VII, 292 n; M. Burrows, IDB II, 843; A. Ne gev, w: Archaeological Encyclopedia of the Holy Land, Jerusalem 1972, 166. 
w „twierdzach” i „pałacach” (w.7), ale poeta koncentruje się na rozwinięciu drugiej części nazwy šălôm. Słowo šâlôm występuje tu trzy razy w trzech kolejnych wersetach, a w czwartym wersecie jest za nie postawione słowo bardzo bliskie znaczeniowo tôb. dobro. Z tym kluczowym słowem šălôm współdźwięczą liczne terminy, znowu nagromadzone z premedytacją: ša'ălû, šelôm, jerûšālāim, jišlājû, šâlôm, šalwāh, šālôm ${ }^{10}$. Każdy werset kończy się zaimkiem dzierżawczym drugiej osoby żeńskiej, przez co strofa uzyskuje nie tylko tak rzadki w poezji hebrajskiej rym, ale też swoisty nastrój uczuciowy: poeta przemawia do Jerozolimy jakby była osobą, piękną dziewczyną, narzeczoną ludu czy matroną. Ona ma swoje sługi (por. Ps 102,15) i swoich przyjaciół, którzy ją kochają. Oto tekst tej strofy:

Ps 122, 6 Niech się modlą o pokój dla Jeruzalem, niech będą bezpieczni ci, co ją miłują ${ }^{11}$

7 Niech będzie pokój w twoich murach, dostatek w twoich pałacach!

8 Przez wzgląd na moich braci i moich bliskich będę mówił: „Pokój niech będzie w tobie!”

9 Przez wzgląd na dom Jahwe, Boga naszego, będę prosił o dobro dla ciebie.

Tak więc pokój napełnia całą Jerozolimę. Ten „pokój” w naszym fragmencie oznacza, podobnie jak w innych teologicznych wypowiedziach ST, pełnię wszelkich dóbr, ich spokojne i bezpieczne zażywanie, a więc pełnię zbawienia. Ale to zbawienie nie jest jakąś magiczną siłą, przysługującą Miastu Świętemu. Psalmista bowiem życzy tego pokoju — zbawienia Jerozolimie jako daru Bożego, o to zbawienie się modli i do takiej modlitwy zachęca innych (por. Ps 69,36). To zbawienie płynie z miejsca obecności Jahwe, z domu Pańskiego. Wychodząc stąd, zbawienie napełnia całe Miasto Święte i udziela się wszystkim „milującym Jerozolimę”, braciom i przyjaciołom psalmisty, pokoleniom Izraela.

2) W architektonicznej strukturze Jerozolimy „dom Jahwe” $\mathrm{i}$,dom Dawida" stanowiły jedną całość, nadającą całemu miastu charakter podwójnej stolicy. Ps 122 wyrazil to pięknie, kładąc na początku i na końcu opisu Jerozolimy „dom Jahwe” a dokładnie w środku poematu - „dom Dawida”. Jest więc zrozumiale, że zbawienie, które wychodzi z domu Pańskiego, spowija przede wszystkim „dom Dawida”, tzn. panującego króla i wszystko, co z nim jest związane.

Psalmy 2 i 110 ukazują wyraźnie, jak Jahwe ze Syjonu staje „po prawicy” króla, by go wspierać w rozprawie z narodami pogańskimi. Zwycięstwo króla i jego ocalenie pochodzi wylącznie od Jahwe. Ps 20 ukazuje uroczystą liturgię

10. Por. H. Gunke l, Die Psalmen übersetzt und erklärt (HAT), Göttingen ${ }^{5}$ 1968, 543.

11. Tak TM. Kierując się względami stylistycznymi i pewnym Ms hebrajskim, BHS uważa za prawdopodobną lekcję 'ōhäläjik, „twoje namioty”. Tak czytał już Gunkel. Ale propozycji tej sprzeciwia się wyraźnie wersjall Q Psa whbjk. Por. M. D a hood, Psalms. Introduction, Translation, and Notes (Anchor Bible 16-18), Garden City-New York $^{11}$ 1982, vol. 3, 207. 
na Syjonie na intencję króla „w dniu ucisku” (w. 2). Król składa Bogu liczne ofiary i całopalenia (w. 4). Wspólnota kultowa wyraża swe prośby przez usta chóru śpiewaków. Cała ta modlitwa koncentruje się znów wokół prośby, spinającej w jedno cały utwór: „Niech cię ocali imię Boga Jakuba” (w. 2) i „Jahwe, zbaw króla!" (w. 10). W środku rozlega się wyrocznia zapewniająca zbawienie: „Teraz wiem, że Jahwe ocali swego pomazańca” - áttāh jādaţi kî hôšîa J̦ahwe $m^{e}$ šîhô (w. 7). Ocalenie ma przyjść nie przez rydwany czy przez konie, tzn. siłę oręża, lecz przez „moc imienia Jahwe” i przez „możne czyny zbawczej Jego prawicy" (ww. 7.8). I zbawienie to ma przyjść właśnie ze Syjonu: „Niech (Jahwe) ześle tobie pomoc ze świątyni, nie cię wspiera ze Syjonu!” (w. 3).

Zaś Ps 18 przedstawia sytuację po odniesionym zwycięstwie: król przychodzi do świątyni (w. 7) i tu śpiewa swoje dziękczynienie dla Jahwe ${ }^{12}$. Według nagłówka psalmu i 1 Sm 22 śpiewakiem jest sam Dawid i wskazówka ta wciąż zachowuje swoją wartość13. We wstępnej inwokacji król nazywa Boga takimi tytułami: „mocy moja”, „ostojo moja”, „twierdzo moja”, „wybawicielu mój”, „skało moja”, „tarczo moja”, „rogu zbawienia mego”, „obrono moja” (ww. 2-3). Biblia Jerozolimska dołącza do w. 2 jeden stych z paralelnego $2 \operatorname{Sm} 22,3$ : „wybawicielu mój, wybawiłeś mnie z ucisku”. Uderza ogromne nagromadzenie tych określeń Boga, z których wszystkie bez wyjątku charakteryzują Jahwe jako obrońcę i wybawiciela ${ }^{14}$. Wszystkie te określenia mają uwypuklić pojęcie centralne, że mianowicie Jahwe jest wybawicielem ( $m^{e}$ falle $\left.t \hat{\imath}\right)$ i zbawicielem (môšia). Wydaje się, że te tytuły wywodzą się z jerozolimskiego środowiska prawa azylu. W tym sakralnym języku doniosłą rolę miało pojęcie „skały” (sûr). Swięta Skała, na której była zbudowana świątynia, uchodziła za niewzruszony punkt oparcia dla całego świata (Ps 125,1). Z biegiem czasu obraz ten przeniesiono na Jahwe, który teraz sam zostaje nazwany „skałą niewzruszoną"15. Do Niego jako do „twierdzy”, „ostoi”, „,tarczy” ucieka się król w godzinie niebezpieczeństwa. Bo „Jahwe ...jest twierdzą zbawienia ( $m \bar{a}^{\prime} \hat{o} n$ ješû́ôt) dla swego pomazańca" (Ps 28,8).

Zbawienie, jakiego król oczekuje od Boga, jest o wiele szersze, aniżeli ocalenie przed atakami nieprzyjaciół. Jak szeroko pojmowane jest to zbawienie, widać najlepiej w Ps 21, który jest liturgiczną, świątynną modlitwą za króla, liturgią sprawowaną w obecności króla, najprawdopodobniej w dzień koronacji czy jej rocznicy, a może liturgią dziękczynną za odniesione zwycięstwo ${ }^{16}$. Utwór wykazuje wiele podobieństw strukturalnych z psalmem poprzednim (20), albowiem są tu również elementy dziękczynienia, prośby i występuje wy-

12. H. J. Kraus, Psalmen (BKAT 15,1-2), Neukirchen-Vluyn ${ }^{4} 1972$, 141; A. De is sle r, Die Psalmen, Leipzig 1965, Bd. 1, $81 \mathrm{nn}$.

13. O. Eissfeld t, Einleitung in das Alte Testament, Tübingen ${ }^{3} 1964,555$; A. La n cellot ti, Salmi (NVB 18), Roma 1977, vol. 1, 157. 41.

14. Por. S. Emilia Ehrlich, Określenia Boga w I Księdze Psalmów, RBL 30 (1977)

15. Ps 18,$3 ; 19,15 ;, 27,5 ; 31,3.4 ; 42,10 ; 62,3 ; 71,3 ; 78,35$.

16. De issler, Psalmen, 92 n. Inni autorzy często akcentują niekreśloność sytuacji Psalmu. 
rocznia prorocka czy kapłańska. Ale najbardziej widoczna jest ta zbieżność w temacie: jak poprzednio tak i teraz chodzi o zbawienie królewskie.

Temat został znakomicie uwypuklony przez strukturę psalmu, w której możemy z łatwością wyróżnić introdukcję (w. 2) i konkluzję (w. 14), przejściowy wiersz 8 , oraz dwie sekcje, ww. 3-7 i $9-13^{17}$. Zamieszczony na początku i na końcu utworu zwrot „Jahwe $b^{e} u z z e k \bar{a}$ ” (ww. 2 i 14) i tworzący znakomitą inkluzję dla całego psalmu, wskazuje na źródło zbawienia królewskiego (w. 2b). Zaś dwie strofy korpusu psalmu są zbudowane na zasadzie paralelizmu antytetycznego: pierwsza rozwija w pięciu formułach temat zbawienia królewskiego, a druga również w pięciu formułach ukazuje zagładę nieprzyjaciół króla. Jest oczywiste, że ta druga strofa, jak każdy paralelizm antytetyczny, ma za zadanie uwypuklić myśl zasadniczą, w tym przypadku zbawienie króla. Zagłada nieprzyjaciół zawiera klęskę w bitwie (w. 9) zniszczenie przez ogień (w. 10), eksterminację potomstwa (w. 11) niepowodzenie przewrotnych planów (w. 12), ucieczkę, może uprowadzenie do niewoli (w. 13). Jest to więc zagłada totalna. Jakże wspaniałe musi być - przez antytezę — zbawienie króla! Oto lista dobrodziejstw, jakie spływają na króla od Boga:

w. 3 spełnienie pragnień serca i życzeń warg

w. 4 błogosławieństwo, złota korona, birekôt t ôb

w. 5 życie najdłuższe, wieczne, hajjîm 'ôlām wā $\bar{a}^{c} e d$

w. 6 chwała zbawienia i dostojeństwo, kābôd je $\check{s}^{c} a t$

w. 7 błogosławieństwo wieczne, radość $b^{e}$ rākôt lāa $a d$ przed Bożym obliczem

Z łatwością można zauważyć, że zgromadzone tu pojęcia, obrazy, symbole, nie tworzą rozwoju myśli, lecz raczej są poetyckim drążeniem centralnego pojęcia „życia po najdłuższe dni, na wieki i na zawsze” (w. 5) ${ }^{18}$. Najbliższym synonimem tego „życia” jest $j$ ešú ${ }^{\prime} \bar{a} h$, zbawienie Boże (w. 6). Jak w Ps 133,3 synonimem zbawienia jest tutaj błogosławieństwo. W naszym fragmencie pojęcie to występuje dwukrotnie w ww. 4 i 7 i za każdym razem w liczbie mnogiej bire$k \hat{o} t, b^{e}$ rākôt. Nie jest to pluralis abstractionis, jak nie jest abstrakcją zbawienie. Jest to pluralis intensitatis, dla wyrażenia bogactwa i pełni owego blogosławieństwa ${ }^{19}$.

Zbawienie królewskie jest kompletne i doskonałe. Niesie ono w sobie wszystko, co zdolne było pomyśleć serce króla i co zdołały wypowiedzieć jego wargi. Tę pełnię wyraża również symbol „złota najczystszego”, rzeczy boskiej par excellence. W promieniach tego zbawienia postać króla jaśnieje boskim blaskiem, staje się odbiciem Jego chwały i łaski. Boskie atrybuty „chwała i blask" (hôd wehādār) stają się teraz udziałem króla (por. Ps 96,6; 104,1). W tym też świetle należy czytać zasadniczą modlitwę króla o „życie wieczne” (hajjîm 'ôlām). Czy chodzi tu tylko o długie osobiste życie króla na ziemi? I czy może chodzi tu tylko o przedłużenie jego egzystencji w długim trwaniu dy-

17. W. Quintens, La vie du roi dans le Psaume 21, Bib 56 (1975) 516-541.

18. Tamże.

19. P. Joüon, Grammaire de l'hébreu biblique, Rome 1965, § 136 g; M. Dahood, Psalms III, $379 \mathrm{n}$. 
nastii zgodnie z obietnicą $2 \mathrm{Sm} 7$ ?

Poważni egzegeci uważają, że chodzi tu o coś więcej ${ }^{20}$. „Życie króla na wieki" powinno również stać się partycypacją w pełni życia Jahwe. Musi tu chodzić również o szczęśliwe życie króla po jego śmierci. Król modli się, aby — raz „dołączony do ojców” - mógł na zawsze oglądać zbawienie, które Jahwe przyniósł swemu ludowi na zawsze przez niego i przez przedstawicieli jego dynastii.

3) Zbawienie, jakie Bóg zlewa na Jerozolimę i na swego pomazańca, jest ostatecznie przeznaczone dla Izraela, dla całego ludu wybranego i każdego pojedynczego Izraelity.

Nie inaczej bowiem jak przez króla panującego na Syjonie, w Izraelu zapanują pokój i sprawiedliwość, a kraj napełni się obfitością wszelkich dóbr (Ps 72,3-7.16). Nie kto inny jak król Dawidowy ma wybawić (gãál) biednych i uciśnionych z nędzy i ocalić (jāša Hiff) ich życie od śmierci (Ps 72,13-14). Przez tego króla spełni się obietnica dana Abrahamowi i błogosławieństwo Boże spłynie na Izraela i na wszystkie narody $(72,17)$. Toteż osadzenie na Syjonie króla Dawidowego jest według Ps 2 bożym aktem zbawczym ${ }^{21}$.

Ps 147B, 12-13 zaprasza Jerozolimę do wielbienia Boga za to, że umacnia jej bramy i błogosławi jej synom oraz zapewnia pokój granicom, tzn. roztacza swą opiekę nad całą ziemią Izraela. Dlatego uciśniony, znajdujący się w jakimkolwiek niebezpieczeństwie, Izraelita zwracał swój wzrok i myśli ku Jerozolimie, ku „świętemu pałacowi Jahwe” (Jon 2,5-8), skąd spodziewal się ratunku i pociechy. Patrząc na biedę i ucisk "swojego ludu” (Ps 14,4-5), psalmista woła do Jahwe jako jedynej ucieczki:

„Niechże się okaże ze Syjonu zbawienie Izraela!

Kiedy Jahwe odmieni losy swego ludu,

rozraduje się Jakub, ucieszy się Izrael."

(Ps 147,7).

Psalmista wygląda i oczekuje dla całego Izraela jakiegoś totalnego obrotu spraw, zbawczego zwrotu obejmującego wszystkie dziedziny życia ${ }^{22}$, który przyniósłby ludowi radość i wesele. Ten zwrot powinien nadejść „,ze Syjonu”, z siedziby Boga Izraela. Pan, „co mieszka na Syjonie” (Ps 9,12) i jest „królem na wieki wieków” (Ps 10,16) ${ }^{23}$, jest wzywany jako „ucieczka dla uciśnionego" i „mściciel krwi ubogich” (Ps 9,10.13). On może biedaka „podnieść z bram śmierci” $(9,14)$, a ten po ocaleniu stanie w ,bramach Córy Syjońskiej”, by wysławiać wielkość Bożego zbawienia (ww. 14.15). Jakże znamienne jest to ze-

20. A. Deissle r, Psalmen, 93; tenże: Das lobpreisende Gottesvolk in den Psalmen, w: Sentire Ecclesiam, Festschrift für K. Rahner, Freiburg 1961, 326; G. von Rad, Theologie des Alten Testaments, München ${ }^{6} 1969$, Bd. 1, 332; Quint e ns, art. cyt., 531.

21. R. Press, Jahwe und sein Gesalbter. Zur Auslegung von Psalm 2, ThZ 13 (1957) 329.

22. Zwrot šûb ('et) šebût znaczy „odmienić czyjś los na lepsze, przywrócić do poprzedniego szczęścia”. Por. Iz 52,8; Ps 53,7; 126,1; Nah 2,3. Zob. F. Zo rell, Lexicon hebraicum Veteris Testamenti, Roma 1968, 826.

23. Psalmy 9 i $10 \mathrm{w}$ TM rozdzielone, stanowią niewątpliwie jedność literacką, o czym świadczą akrostych alfabetyczny oraz starożytne przekłady $\mathrm{LXX} \mathrm{i} \mathrm{Vg}$. 
stawienie w dwóch kolejnych wierszach dwóch zwrotów: ša ărê māwet i ša ‘̆âê bat-Sijjôn ${ }^{24}$. W tej antytezie „bramy śmierci” — „bramy Córy Syjońskiej” — miasto Jerozolima jawi się jako uosobienie życia, młodości, szczęścia.

Psalmiści wiedzieli doskonale, że życie nie jest jakąś siłą ze siebie wychodzącą ani w sobie ugruntowaną 25 . W tym względzie oni widzą się jako całkowicie zależni od Boga. Tylko On jest „Bogiem mego życia” (Ps 42,9), tylko „przy Tobie jest źródło życia" (Ps 36,10$)$ - wyznają psalmiści z całą pokorą. Tylko u Niego jest zbawienie i nie ma go u książąt tego świata. Gdy nieprzyjaciele naigrawają się z psalmisty, że Bóg go absolutnie nie ocali, to on wyznaje, że Jahwe jest jego tarczą i woła doń: „Powstań Jahwe, zbaw mnie, Boże mój!” (Ps 3,3.8). Znane z historii Arki zawołanie: qûmāh Jahwe! (Lb 10,35), wskazuje, że psalmista spodziewa się ratunku od tronu Jahwe na Syjonie. I rzeczywiście: „Jahwe odpowiedział mi z góry swej świątyni” (w. 5) i poraził nieprzyjaciół psalmisty (w. 8). W konkluzji może psalmista podjąć szydercze słowa jego wrogów, ale w przeciwnym sensie: „U Jahwe jest zbawienie!” (w. 9). Ta piękna inwersja jest odzwierciedleniem całkowitej odmiany losu psalmisty, jaka się dokonała w świątyni ${ }^{26}$.

Jak bogate jest to zbawienie, ukazuje Psalm 146: Jahwe, Bóg Syjonu, który „króluje na wieki” (w. 10), jest pomocą dla Izraela, a więc oddaje sprawiedliwość uciśnionym, daje chleb głodnym i wolność jeńcom, przywraca wzrok niewidomym, podnosi pochylonych, miłuje sprawiedliwych, strzeże przychodniów, chroni sierotę i wdowę (ww. 5-9). Trzeba się strzec przed pochopnym, a niestety jakże częstym, ograniczaniem tego zbawienia psalmistów do sfery ziemskiego życia, do doczesnych dóbr ziemskich, do uwolnienia z niewoli, z rąk nieprzyjaciół, podźwignięcia z choroby. Jeszcze wyraźniejszy obraz zbawienia jawi się w Ps 85, jednym z najpiękniejszych psalmów, włączonym do zbioru Korachitów ${ }^{27}$. Znajdujący się w głębokiej niedoli ${ }^{28}$ Izrael błaga Boga o zbawienie: „Odnów nas, Boże, Zbawco nasz!” (w. 5a) i ponawia wyznanie: „Ty sam odnowisz nasze życie” (w. 7). Jest oczywiste, że Izrael modli się tu o nowe, pelniejsze życie ${ }^{29}$, a więc takie, gdy Bóg „,odpuści winę swojemu ludowi” (w. 3), kiedy „udzieli pokoju swoim świętym”, kiedy „Jego Chwała zamieszka na ziemi”, kiedy „milość i wierność spotkają się razem”, a „sprawiedliwość i pokój się ucałują" (9-12). Słusznie zinterpretował ten psalm Euzebiusz z Cezarei ${ }^{30}$ mówiąc, że to zbawienie dokonało się w Jezusie Chrystusie i że to

\footnotetext{
24. A. Deissler, Psalmen, 57.

25. H. J. Kraus, Theologie der Psalmen (BKAT 15/3), Neukirchen-Vluyn 1979, 204.

26. Por. J. S. Kselman, Psalm 3: A Structural and Literary Study, CBQ 49 (1987) $572-580$.

27. E. Lipiński, Psaumes I. Formes et genres littéraires, DBSuppl IX, 86-92; tenże: Le Psaume 85. Le salut set proche, „Assemblées du Seigneur” 5 (1966) 24-31.

28. Często egzegeci uważali, na podstawie wyrażenia šabtā šebît (w. 2), że tą niedolą jest wygnanie. Jednakże ten zwrot należy rozumieć tak samo jak wyrażenie šûb šebût w Ps 14,7, tzn. „odmienić los”. Lipińs ki, Le Psaume 85, s. 24, nota 2; Dahood, Psalms II, 286.

29. New English Bible przekłada ,give us a new life”.

30. $\mathrm{PG} 23,1020 \mathrm{n}$.
} 
zbawienie ujrzał na Syjonie Symeon, gdy wziął na swe ręce Jezusa i rzekł: „Nunc dimittis servum tuum, quia viderunt oculi mei salutare tuum" ( $\mathrm{k}$ 2,29-30).

Toteż miejsce obecności Boga na Syjonie jest dla psalmistów źródłem życia. Tutaj „synowie Adama chronią się w cieniu Jego skrzydeł”, tutaj On „syci ich tłuszczem swego domu”, ,poi potokiem swoich rozkoszy”, „albowiem w Tobie jest źródło życia i w Twojej światłości oglądamy światłość" (Ps 36,8-10). Tutaj w cieniu Miejsca Najświętszego, pod rozpiętymi skrzydłami cherubinów, znajduje pobożny upragniony azyl, obronę przed prześladowcami. Tu bierze udział w uczcie ofiarnej šelāmîm, dającej wspólnotę z Bogiem i z braćmi. Na dziedzińcach domu Pańskiego Izraelita pije z „kielicha zbawienia" (Ps 116B,13.19). Tutaj psalmistę spowija światłość, inny symbol zbawienia (Iz 45,7; 59,9; Jr 13,16). Wszystkie te obrazy wyrażają i materializują zbawienie, łaskę Bożą (Ps 36,8). Wpatrując się w Boga w świątyni, psalmista dochodzi do wniosku, że „łaska Twoja jest cenniejsza od życia” (Ps 63,4.5). To światło, to zbawienie, ta łaska jest na Syjonie tak obfita, że psalmista porównuje ją do rosy Hermonu: „Jak rosa Hermonu, która spada na górę Syjon; bo tam udziela ${ }^{31}$ Jahwe błogosławieństwa, życia na wieki" (Ps 133,3). Rosa w okolicach góry Hermon jest tak obfita, iż rankiem ma się wrażenie jakoby nocą spadł rzęsisty deszcz ${ }^{32}$. Tak też obficie Bóg wylewa na Syjonie swe błogosławieństwo i ,życie na wieki”. Wyrażenie hajjîm ąd hā'ôlām (życie na wieki) jest nieraz tłumaczone jako długie życie na ziemi ${ }^{33}$. Ale już sama rosa w Iz 26,19 symbolizuje zmartwychwstanie i nieśmiertelność. Pełnia życia, jakiej szukał pobożny u Boga na Syjonie, była oczywiście czymś więcej niż nawet najdłuższe życie na ziemi. Świądczą o tym rozliczne wypowiedzi Psałterza.

Najpiękniejsze świadectwo tej wiary zostawil pewien mędrzec izraelski w Ps 73, który zagłębiając się w trudnym problemie powodzenia grzeszników, o mało nie uległ pokusie „światowego myślenia” (w. 15). Na udręczone serce spłynęło jednak nieoczekiwanie światło Boże, skoro psalmista „wszedł él miq$d^{e}$ šê El". Jedni egzegeci thumaczą to ostatnie określenie przez „tajemnice Boże” albo „święte sprawy Boże"34. Inni sądzą, że w określeniu tym jest zawarte Pismo święte, objawienie mądrości Bożej (por. Prz 9,1-7; Syr 14,21-27). Ale dzisiaj coraz liczniejsi egzegeci widzą tu określenie świątyni ${ }^{35}$, a użyta tu liczba mnoga staje się zupełnie zrozumiała w świetle podobnych

31. Hebr. siwwāh (RSV ,has commanded”, BJ ,a voulu”) z biernikiem rzeczy przydzielonej nabiera znaczenia „udzielać, obdarowywać” (La Bible de la Pléiade „,a conféré").

32. G. A. Smith, The Historical Geography of the Holy Land, London ${ }^{3}$ 1895, 65. Piszący te słowa miał możność doświadczyć tego zjawiska podczas podróży po Jordanii.

33. Tak np. interpretuje L. E. Toombs, The Psalms. w: The Interpreter's One-Volume Commentary on the Bible, ed. by Ch.M. Laymon, Nashville-New York 1971, 298.

34. J. Prado, De Veteris Testamenti doctrina sive de libris didacticis V.T. (Praelectiones Biblicae, ed. H.Simón), Torino-Madrid 1954, vol. 2, 238. Podobnie Buber, Kittel, Psalterium Pianum, Biblia Tysiąclecia.

35. E. B e a c a mp, Voie nouvelle pour l'exégèse du Psaume 73, w: Studia Hierosolymitana in onore di P.B. Bagatti (Studii Biblici Franciscani Collectio Maior 23), Jerusalem 1976, vol. 2, 44-46. Tak też uważają H. Schmidt, H.J. Kraus, J. Harvey, S. Łach. 
ugaryckich określeń mieszkania bóstwa. Zarówno Septuaginta jak i Wulgata oddały termin w liczbie pojedynczej „sanctuarium Dei”. Teraz psalmista widzi nieuchronną ruinę grzeszników i swoje szczęśliwe przeznaczenie:

Ps 73, 23 Lecz ja nieustannie jestem z Tobą,

Tyś ujął moją prawicę;

24 Prowadzisz mnie według swojej rady, i na koniec przyjmujesz mnie do Chwały.

25 Kogóż mam w niebie poza Tobą?

A gdy z Tobą jestem, nie cieszy mnie ziemia.

26 Niszczeje moje ciało i moje serce, opoką mego serca i częścią moją - Bóg na wieki.

Znalazłszy się w obecności Boga, psalmista czuje Jego podtrzymującą i prowadzącą obecność: „Tyś ujął moją prawicę”. Bóg prowadzi psalmistę ku ostatecznemu spełnieniu, ku novissima (áhar), które jawi się diametralnie inaczej niż áhărît grzeszników: „,na koniec przyjmujesz mnie do chwały”. Kierując się LXX (meta doksēs) i Wulgatą (cum gloria), trzeba by hebrajskie kābôd tlumaczyć jako accusatif de maniére ${ }^{36}$ „z chwałą” 37 . Tutaj jednak „chwała” zdaje się być uosobionym atrybutem Bożym, Bożym majestatem, hipostatą ${ }^{38}$. I dlatego „przyjmujesz mnie do chwały”, znaczy tyle co „do siebie”"39. Godne zauważenia jest też użycie czasownika lāqah, który w dwóch sławnych przypadkach Henocha $(\mathrm{Rdz} 5,24)$ i Eliasza $(2 \mathrm{Krl} 2,1)$ wyraża nie co innego jak porwanie do nieba, wniebowzięcie. W Ps 49, który traktuje o tej samej materii co Ps 73, termin ten wyraża wyzwolenie z „mocy szeolu”(w. 16). Wobec tej świetlanej perspektywy, kiedy opoką i wiecznym dziedzictwem staje się Bóg, wszelkie ziemskie dobra i korzyści tracą swój blask. Nawet „ciało”, a więc całe to obecne życie psalmisty z tym wszystkim, co dobrego może zaoferować w sferze fizycznej ( $b \bar{a} s ́ a ̂ r r)$ czy duchowej (lebāb), nie ma większego znaczenia. Psalmista gotów jest wyrzec się tego wszystkiego dla dobra najwyższego, jakim jest Bóg 40 .

4) Zbawienie skumulowane w Mieście Bożym jest tak obfite, że nie może się ograniczyć tylko do synów Izraela. W przyszłych czasach rozleje się ono jak potężna rzeka na wszystkie kraje i narody. Taką wizję Jerozolimy „rodzącej” dla Boga wszystkie narody ziemi kreśli Psalm 87. Pieśń ta wychwala najpierw założoną na świętej górze siedzibę Najwyższego (Króla), przez Niego ukochaną i umacnianą (ww. 2.5). Korpus psalmu stanowią wiersze 4-6, a ich tematem jest rodzenie się na Syjonie:

36. Joü on, Grammaire, $\S 102$ s i 126 d.

37. Tak tłumaczy S. Łach, Psalmy, Poznań 1986, 183. Natomiast Bible de Jérusalem „derriére ta gloire tu m'attireras".

38. Por. M. Weinfeld, käbōd, TWAT IV, 34.

39. Nasz przekład reprezentują również: Psalteruim Pianum, BT, Borowski i in.

40. „In conclusione: vita con Dio, sentita e goduta con visione «mistica», oltre la tomba, sarebbe quanto il Salmo 73 ci offre come soluzione al lancinante problema che per lungo periodo ha tormentato l'anima ebraica nei suoi migliori rappresentanti, le cui luci sono state come bagliori forieri del N.T." 
Ps 87, 4 Wpiszę ${ }^{41}$ Rahab i Babel wśród tych, co mnie znają, oto Filistea i Tyr razem z Kusz: „Ten się tam narodził”.

5 A Syjon będą nazywać matką: „Każdy bowiem urodził się w niej” i Najwyższy sam ją umacnia.

6 Jahwe wylicza w spisie narody „Ten się tam narodził".

W tych wersetach poeta jakby ,podsłuchiwał” słowa czynionych przez Boga zapisów i ujmuje je w formę wyroczni ${ }^{42}$. Sporządzanie dokładnych rejestrów prawdziwych synów Izraela było wielką troską jego przywódców zarówno w dobie formowania się Izraela na pustyni (por. Lb 1-3;26) jak i w czasach odbudowy po niewoli (por. Ezd 2; Ez 13,9). Obraz ten przeniesiony na plan duchowy dal początek idei „księgi żywych”, sporządzanej w niebie przez samego Boga, a zawierającej imiona wszystkich sprawiedliwych, tzn. członków wspólnoty Bożej (por. Ps 69,29; Dn 12,1; Ap 20,15). Treść Bożego zapisu jest bardzo ciekawie wkomponowana w korpus psalmu, stanowiąc pewną stylistyczną całość, chiastyczną i rymującą się:

w.4b zeh jullad šām

w.5a iš weiš jullad bāh

w.6b zeh jullad šām

Przez ten akt rejestru jakaś osoba zostaje urzędowo uznana za „obywatela” miejsca, w tym wypadku Jerozolimy, miasta Bożego. Akt ten więc oznacza duchowe „usynowienie”, Bożą adopcję. Owa adopcja rozciąga się na Rahab, Babel, Filisteę, Tyr i Kusz, podjęte w zaimkach zeh (dwukrotnie) i iš weiš. Obydwa zaimki w naszym kontekście odnoszą się do zbiorowości, a drugi zawiera nadto ideę kompletności „,jak jeden mąż, każdy”43. Ten środkowy element chiazmu wyraża myśl zasadniczą ${ }^{44}$. I oto „ten” staje się w punkcie szczytowym „każdy”, a przysłówek „tam” zostaje zastąpiony złożeniem zaimkowym „w niej”, czyli w Jerozolimie. I dlatego mało prawdopodobna jest opinia Krausa ${ }^{45}$, że chodzi tu o Izraelitów rozproszonych w diasporze z prozelitami spośród innych narodów. Psalm ukazuje, i to $\mathrm{z}$ wielką emfazą, wizję wejścia do ludu Bożego licznych, tzn. wszystkich ludów ziemi. W wyliczeniu tym nie chodzi autorowi o podkreślenie myśli, że nawet tacy wrogowie Izraela jak Egipt (Rahab) czy Babilon zostaną przyjęci do grona synów Boga, ale wyliczając narody dokładnie z czterech stron świata względem Palestyny, wyrazil powszechność, uniwersalizm owego nawrócenia. W ten oto sposób Jerozolima ujawni swoje

41. Hebr. 'azkîr, dosłownie „wspomnę, wymienię”, w świetle w. 6 i w powiązaniu z nazwą urzędnika dworskiego mazkîr, którego zadaniem było spisywanie wydarzeń ( $2 \mathrm{Sm}$ 8,16; 1 Krn 4,3), nabiera znaczenia „wpisywać”. Por. BDB 271; Zorell, Lexicon VT, 209.

42. H. J. Kraus, Psalmen, 601.

43. „man für man, jeder wer es auch sei”- HAL 42.

44. Por. J. Breck, Biblical Chiasmus: Exploring Structure for Meaning, BThB 17,2 (1987) $70-74$.

45. Psalmen, $604 \mathrm{n}$. 
duchowe macierzyństwo względem narodów: „A Syjon będą nazywać matką" (w. 5a). Tekst masorecki ma lekcję ,a będą mówić o Syjonie”, ale w tym przypadku lepsza jest lekcja LXX: Mētēr Siōn erei anthrōpos. Należy więc uzupełnić tekst hebrajski i czytać: $w^{e}$ lassijjôn ém jēea ämar ${ }^{46}$. Psalm bowiem rozwija ten sam obraz co Drugi Izajasz, obraz Syjonu jako matki ${ }^{47}$. Jest tylko jedna różnica: gdy w prorockich przedstawieniach te ludy jawią się jako niższa kategoria w porównaniu $\mathrm{z}$ rodowitymi Izraelitami, to tu wszyscy są równi.

Oni to razem zbratani z ludem Izraela, usynowieni jako lud Boży, łączą się w zgodnej liturgii na Syjonie: „I tańcząc śpiewać będą: wszystkie moje źródła są w tobie" (w. 7). Ten ostatni zwrot TM jest najrozmaiciej poprawiany poczynając od starożytnych przekładów ${ }^{48}$, ale niepotrzebnie, gdyż zawiera on bardzo dobrą myśl: Jak Bóg był nazywany „źródłem życia”, tak teraz Matka Jerozolima, mieszkanie Najwyższego, zawiera w sobie źródło, co więcej wszystkie prawdziwe źródła. Za F. Zorellem ${ }^{49}$ możemy powtórzyć: „Fontes lucis, gaudii, pacis, spei, denique omnes fontes quorumvis bonorum habemus in te, $o$ Sion, o sancta Christi ecclesia!”. I tu znajdujemy się w sercu i u szczytu teologii Syjonu. Jest to już Syjon mesjański. W 4 Ezd zostanie powiedziane, że Syjon jest „matką wszystkich nas”, a św. Paweł to potwierdzi „Jeruzalem jest naszą matką" $(\mathrm{Ga} 4,26)$. Sw. Augustyn wszystko to zrekapitulował mówiąc, że w Ps 87 śpiewa się o mieście, którego my jesteśmy mieszkańcami, jeśli jesteśmy chrześcijanami ${ }^{50}$.

Tarnów

KS. TADEUSZ BRZEGOWY

46. Tak czytają W.S. McCullough, Kraus, NEB. Zob. BH.

47. J. H. Schmitt, The Motherhood of God and Zion as Mother, RB 92 (1985) 564: „Psalm 87 is the hapiest depiction of Mather Zion. The Psalm, thogh quite difficult in the Masoretic vocalization, is a marvelous glorying in the motherhood of Zion". Por. R. Lack, La symbolique du Livre d'Isäie, Rome 1973, 220-228; R. A brame k, Psalm 87 o Matce narodów i źródle ich życia, „Jasna Góra” 4 (1986) zesz. 2, 17-25; A. Colunga, Jerusalém, la Ciudad del Gran Rey, EstB 14 (1955) 272.

48. Por. BHS. Ale już św. Hieronim w przekładzie iuxta Hebraeos tłumaczył „omnes fontes mei in te". Tak też czynią Prado, Łach, BT.

49. F. Zor ell, Psalterium ex hebraeo latinum, Romae 1928, 154.

50. Enarrationes in Ps 86, nota 1. PL 37, 1100. Por. G. Be d o u elle, Pragnienie ogladania Jerozolimy, „Communio” 6 (1986) nr 2, 57-70.

Ks. Antoni Tronina

\section{ŚWIADECTWA EPIGRAFICZNE O POCZATKACH IZRAELA}

Wczesna historia szczepów, które z czasem przyjmą wspólną nazwę „Izrael”, pełna jest niejasności. Wyjdźmy od danych Księgi Rodzaju, która przedstawia przodków Izraela jako półkoczowników, przemieszczających się stop- 